\title{
Effects of ivabradine hydrochloride combined with trimetazidine on myocardial fibrosis in rats with chronic heart failure
}

\author{
DONGWEN MA ${ }^{1}$, TONG XU² ${ }^{2}$ GUOQIANG CAI ${ }^{1}$, XILIN WU $^{3}$, ZHENDONG LEI $^{4}$, \\ XINMEI LIU ${ }^{1}$, JUNYING LI ${ }^{1}$ and NING YANG ${ }^{5}$ \\ Departments of ${ }^{1}$ Cardiac Critical Care Medicine and ${ }^{2}$ Gastrointestinal Surgery, Affiliated Hospital of \\ Jining Medical University, Jining, Shandong 272000; ${ }^{3}$ Department of Cardiology, The First Affiliated Hospital of \\ Guangxi University of Science and Technology, Liuzhou, Guangxi 545002; ${ }^{4}$ Department of Interventional Cardiology, \\ General Hospital of Guizhou Panjiang Investment Holding Group Co., Ltd., Liupanshui, Guizhou 553536; \\ ${ }^{5}$ Health Management Center, Affiliated Hospital of Jining Medical University, \\ Jining, Shandong 272000, P.R. China
}

Received January 24, 2019; Accepted May 28, 2019

DOI: $10.3892 /$ etm.2019.7730

\begin{abstract}
Effects of ivabradine hydrochloride (Iva) and trimetazidine on myocardial fibrosis (MF) in rats with chronic heart failure (CHF) werфe explored. Fifty Wistar rats were randomly divided into sham operation, model, Iva, trimetazidine and combined drug group with 10 rats each. All rats except those in sham operation group were subjected to establish $\mathrm{CHF}$ model by constricting the abdominal aorta. After successful modeling, rats in the sham operation and model group received normal saline $(10 \mathrm{mg} / \mathrm{kg})$ gavage daily, the Iva group received Iva $(10 \mathrm{mg} / \mathrm{kg})$ gavage, the trimetazidine group received trimetazidine $(10 \mathrm{mg} / \mathrm{kg})$ gavage, and the combined drug group were given Iva $(10 \mathrm{mg} / \mathrm{kg})$ and trimetazidine $(10 \mathrm{mg} / \mathrm{kg})$ gavage for 12 weeks. The changes of hemodynamic indexes and heart rate, connective tissue growth factor (CTGF) and superoxide dismutase (SOD) levels as well as transforming growth factor $\beta 1$ (TGF- $\beta 1$ ) and collagen I (COL-I) expression levels in myocardial tissue of each group were detected. Compared with sham operation group, the left ventricular end-diastolic pressure (LVEDP) level, CTGF expression, TGF- $\beta 1$ mRNA and COL-I mRNA expression levels in model group increased significantly, but the $\pm \mathrm{dp} /$ $\mathrm{dt}_{\max }$ and SOD content in myocardial tissue decreased significantly. Compared with model group, the LVEDP level, CTGF expression, TGF- $\beta 1$ mRNA and COL-I mRNA expression levels in Iva group, trimetazidine group and combined drugs
\end{abstract}

Correspondence to: Dr Ning Yang, Health Management Center, Affiliated Hospital of Jining Medical University, 89 Guhuai Road, Jining, Shandong 272000, P.R. China

E-mail: ydesb5@163.com

Key words: ivabradine hydrochloride, trimetazidine, chronic heart failure, myocardial fibrosis decreased significantly, but the $\pm \mathrm{dp} / \mathrm{dt}_{\max }$ and the SOD content in myocardial tissue increased significantly $(\mathrm{P}<0.05)$. Changes in the combined drug group were the most notable $(\mathrm{P}<0.05)$. Iva combined with trimetazidine reduces LVEDP in rat with CHF, increases SOD content, and inhibits CTGF expression and TGF- $\beta 1$ and COL-I expression levels in myocardial tissues, thus achieving the inhibitory effect on MF.

\section{Introduction}

Heart failure is a clinical syndrome with pathophysiological changes in heart caused by impaired ventricular diastolic or systolic function due to damaged cardiac function or abnormal internal structure of heart (1). Chronic heart failure (CHF), as one of the leading causes of cardiovascular disease death, has a serious impact on health and quality of life of patients (2). Studies have shown that myocardial fibrosis (MF) is the most important pathological basis of CHF (3). Other studies $(4,5)$ show that MF actually refers to a process in which a large amount of collagen fibers in the heart matrix aggregate or collagen compositions change.

Ivabradine hydrochloride (Iva), a highly specific If channel drug with controling effect on sinus heart rate (6), also delay heart failure and improves heart function (7). Due to its unique dual action mechanism, Iva can control spontaneous diastolic depolarization in sinoatrial node and regulate heart rate by selectively and specifically inhibiting cardiac pacing If current, providing a new therapeutic idea for heart failure (8). Trimetazidine, as a myocardial metabolic drug, is also widely used in cardiovascular therapy due to its antioxidation and anti-ischemia effects (9). It has been shown that trimetazidine has inhibitory effects on the activities of myocardial fatty acids and oxidation-related enzymes, which is conducive in increasing myocardial productivity and thus improving ventricular function (10). Although these two drugs are currently used in $\mathrm{CHF}$, studies on their effects on MF are still rare. Therefore, $\mathrm{CHF}$ rat models were established and the effects of Iva and trimetazidine on MF were observed in this 
Table I. Primer sequences.

\begin{tabular}{lll}
\hline Factor & \multicolumn{1}{c}{ Upstream primer } & \multicolumn{1}{c}{ Downstream primer } \\
\hline TGF- $\beta 1$ & 5'-TGGACCGCAACAACGCAATCTA-3' & 5'-CACCTCGACGTTTGGGACTGATC-3 \\
COL-I & 5'-ATGTCTGGTTTGGAGAGAGCA-3' & 5'-GAGGAGCAGGGACTTCTTGAG-3' \\
$\beta$-actin & 5'-GAGAGGGAAATCGTGCGTGAC-3' & 5'-CATCTGCTGGAAGGTGGACA-3' \\
\hline
\end{tabular}

study in order to provide more theoretical data for the treatment of CHF.

\section{Materials and methods}

Animals and experimental materials. A total of $50 \mathrm{Wistar}$ male rats weighing $220.51 \pm 10.24 \mathrm{~g}$ were selected and purchased from Shanghai Slaccas Experimental Animal Co., Ltd., with a production license of SCXK (Shanghai) 2012-0002, fed at a constant temperature of $22^{\circ} \mathrm{C}$ with normal circadian rhythm and free diet. Iva was purchased from Servier Laboratories. Trimetazidine was purchased from Beijing Wansheng Pharmaceutical Co., Ltd. Sodium pentobarbital was purchased from Hubei Hongyun Long Biological Technology Co. Ltd. Connective tissue growth factor (CTGF) polyclonal antibody was purchased from Invitrogen; Thermo Fisher Scientific, Inc. Superoxide dismutase (SOD) kit was purchased from Dojindo Molecular Technologies, Inc. Primary mouse anti-rat CTGF (cat. no. AMAB91366; dil, 1:1,000) and $\beta$-actin monoclonal antibodies (cat. no. A1978; dil, 1:400), secondary rabbit anti-mouse polyclonal antibody (cat. no. SAB3701212; dil, 1:100) used in western blot analysis were purchased from Sigma-Aldrich; Merck KGaA. BCA quantitative kit was purchased from Beijing Solarbio Science \& Technology Co., Ltd. RT-qPCR kit and minScript reverse transcription kit were purchased from Takara Biotechnology Co., Ltd. Biological signal recorder system was purchased from Anhui Zhenghua Biological Instrument Equipment Co., Ltd.

The study was approved by the Ethics Committee of The Affiliated Hospital of Jining Medical University (Jining, China).

Establishment and grouping of animal models. Ten rats were randomly selected as sham operation group, and the other rats were all used to construct CHF rat model by constricting the abdominal aorta. The specific steps were: All rats were fasted for more than $12 \mathrm{~h}$ before surgery, then $3 \%$ pentobarbital sodium solution was prepared and injected intraperitoneally $(0.15 \mathrm{ml} / 100 \mathrm{~g})$ to anesthetize the rats. After anesthesia, a $2.5 \mathrm{~cm}$ long incision was made in the abdominal skin along the anterior midline at the costal arch, then the left renal artery was freed from the abdominal aorta at the upper part by entering the abdominal cavity. Next, the abdominal aorta was placed in parallel with needle 7 and ligated with thread 0 , the needle was taken out afterwards. Abdomen was closed layer by layer after confirming that the blood flow of the abdominal aorta was unobstructed. Rats in the sham operation group were only given abdominal aorta separation, not ligated. All rats received 20,000 units of penicillin injections in abdominal cavity for 3 consecutive days after operation. After 4 weeks of continuous feeding, $10 \mathrm{CHF}$ rats were randomly selected for hemodynamic detection. Left ventricular end-diastolic pressure (LVEDP) $\geq 15 \mathrm{mmHg}$ indicated the modeling was successful. Forty rats with successful modeling were randomly divided into model, Iva, trimetazidine and combined drug group (Iva + trimetazidine) with 10 rats each. Rats in the sham operation and model group were given $10 \mathrm{mg} / \mathrm{kg}$ of normal saline daily, rats in the Iva group were given $10 \mathrm{mg} / \mathrm{kg}$ of Iva daily, rats in the trimetazidine group were given $10 \mathrm{mg} / \mathrm{kg}$ of trimetazidine daily, and rats in the combined drug group were given Iva $(10 \mathrm{mg} / \mathrm{kg})$ and trimetazidine $(10 \mathrm{mg} / \mathrm{kg})$ daily for 12 weeks of continuous treatment. The changes of hemodynamic indexes, heart rate, CTGF and SOD levels as well as transforming growth factor $\beta 1$ (TGF- $\beta 1$ ) and collagen I (COL-I) expression levels in myocardial tissue in each group were detected.

\section{Index detection method}

Hemodynamic index detection. After the treatment, the right common carotid artery was retrograde intubated to the left ventricle, and then the other end was connected to the pressure transducer containing multimedia biological signal recorder system in order to record maximum rising and decreasing rate of the left ventricular end-diastolic pressure (LVEDP) and the left ventricular pressure $\left( \pm \mathrm{dp} / \mathrm{dt}_{\max }\right)$.

Detection of SOD and CTGF. The myocardial tissue was homogenized by a high-speed homogenizer, then the expression of SOD was detected using enzyme-linked immunosorbent assay (ELISA), and the specific operation strictly followed the kit instructions. The content of CTGF in the myocardial tissue was detected by western blot analysis. The specific method was as follows: Total protein in the myocardial tissue was extracted, and separated with $10 \%$ SDS-PAGE, then transferred to PVDF membrane. The membrane was blocked with $5 \%$ skimmed milk at room temperature for $1 \mathrm{~h}$, then incubated overnight at $4^{\circ} \mathrm{C}$ with primary mouse anti-rat CTGF (cat. no. AMAB91366; dil, 1:1,000) and $\beta$-actin monoclonal antibodies (cat. no. A1978; dil, 1:400) both from Sigma-Aldrich; Merck KGaA and incubated at $37^{\circ} \mathrm{C}$ for $1 \mathrm{~h}$ with secondary rabbit anti-mouse polyclonal antibody (cat. no. SAB3701212; dil, 1:100; Sigma-Aldrich; Merck KGaA). The protein bands on the membrane were developed with DAB developer.

Detection of TGF- $\beta 1$ mRNA and COL-I mRNA expression by $R T-q P C R$. The myocardial tissue of rats was cut and then added with TRIzol reagent to extract total RNAs. The purity and concentration of RNAs were detected by an ultraviolet spectrophotometer. According to the instructions of reverse transcription kit, $1 \mu \mathrm{g}$ of total RNA was reverse transcribed to cDNA, with reaction parameters of $30^{\circ} \mathrm{C}$ for $10 \mathrm{~min}, 42^{\circ} \mathrm{C}$ 
Table II. Expression of hemodynamic indexes in each group.

\begin{tabular}{|c|c|c|c|c|c|c|c|}
\hline Index & $\begin{array}{l}\text { Sham operation } \\
\text { group }(n=10)\end{array}$ & $\begin{array}{c}\text { Model } \\
\text { group }(n=10)\end{array}$ & $\begin{array}{l}\text { Iva group } \\
\quad(n=10)\end{array}$ & $\begin{array}{l}\text { Trimetazidine } \\
\text { group }(n=10)\end{array}$ & $\begin{array}{l}\text { Combined drug } \\
\text { group }(n=10)\end{array}$ & F value & P-value \\
\hline LVEDP (mmHg) & $6.12 \pm 0.14^{\mathrm{a}}$ & $21.37 \pm 0.79$ & $12.21 \pm 0.68^{\mathrm{a}, \mathrm{b}}$ & $12.63 \pm 0.59^{\mathrm{a}, \mathrm{b}}$ & $7.09 \pm 0.11^{\mathrm{a}}$ & 1252 & $<0.001$ \\
\hline$+\mathrm{dp} / \mathrm{dt}_{\max }(\mathrm{mmHg} / \mathrm{sec})$ & $5210.71 \pm 119.75^{\mathrm{a}}$ & $4182.55 \pm 51.92$ & $4713.91 \pm 111.25^{\mathrm{a}, \mathrm{b}}$ & $4698.75 \pm 112.14^{\mathrm{a}, \mathrm{b}}$ & $5122.76 \pm 118.34^{\mathrm{a}}$ & 149.7 & $<0.001$ \\
\hline$-\mathrm{dp} / \mathrm{dt}_{\max }(\mathrm{mmHg} / \mathrm{sec})$ & $4351.83 \pm 129.54^{\mathrm{a}}$ & $2875.31 \pm 60.88$ & $3451.26 \pm 113.79^{\mathrm{a}, \mathrm{b}}$ & $3398.18 \pm 114.16^{\mathrm{a}, \mathrm{b}}$ & $4268.81 \pm 125.33^{\mathrm{a}}$ & 317.0 & $<0.001$ \\
\hline
\end{tabular}

${ }^{a} \mathrm{P}<0.05$, compared with model group; ${ }^{\mathrm{b}} \mathrm{P}<0.05$, compared with drug group. LVEDP, left ventricular end-diastolic pressure.

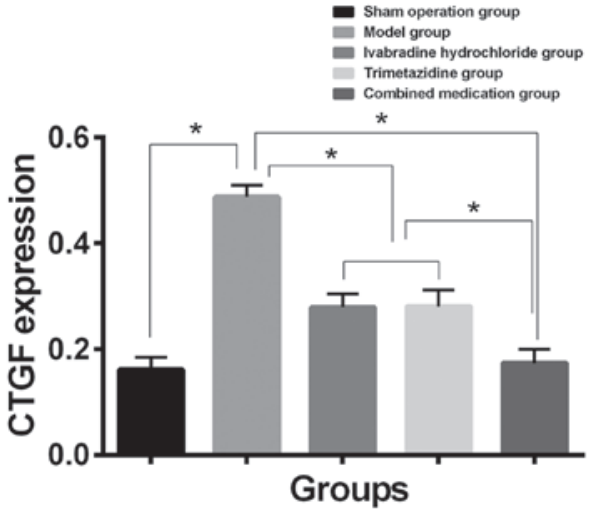

Figure 1. Expression of CTGF in myocardial tissue of each group. Western blot analysis showed that compared with the sham operation group, CTGF expression increased in myocardial tissue of the model group. Compared with the model group, the expression decreased in myocardial tissue of the Iva, trimetazidine and combined drug group $(\mathrm{P}<0.01)$. The changes in the combined drug group were the most notable $(\mathrm{P}<0.05)$, and the expression of CTGF in the Iva and trimetazidine group had no significant difference $(\mathrm{P}>0.05) .{ }^{*} \mathrm{P}<0.05$. CTGF, connective tissue growth factor.

for $30 \mathrm{~min}$ and $95^{\circ} \mathrm{C}$ for $5 \mathrm{~min}$. The transcribed cDNA was used for qPCR amplification, and the system was as follows: $10 \mu 1$ of Taqman PCR Master Mix II, $0.25 \mu 1$ of Takara Ex Taq, $0.5 \mu \mathrm{l}$ of each upstream and downstream primer, $\mathrm{ddH}_{2} \mathrm{O}$ complemented to $20 \mu \mathrm{l}$. $\beta$-actin was used as an internal reference, and the primer sequences are shown in Table I. qPCR reaction conditions: Pre-denaturation at $94^{\circ} \mathrm{C}$ for $2 \mathrm{~min}$, then $95^{\circ} \mathrm{C}$ for $30 \mathrm{sec}$ and $60^{\circ} \mathrm{C}$ for $30 \mathrm{sec}$ for 40 circles, then extension at $72^{\circ} \mathrm{C}$ for $1 \mathrm{~min}$. Real-time quantitative PCR detection was carried out with $\mathrm{qPCR}$ instrument, and the experiment was repeated 3 times. The results were analyzed using the $2^{-\Delta \Delta \mathrm{Cq}}$ method (11).

Statistical analysis. SPSS 19.0 (IBM Corp., Armonk, NY, USA) was used to analyze the experimental data. The measurement data were expressed as mean \pm standard deviation (SD). One-way analysis of variance (ANOVA) was used to compare the differences among groups, and the Dunnett's t-test was used for the following pairwise comparison. The difference was statistically significant with $\mathrm{P}<0.05$.

\section{Results}

Expression of hemodynamic indexes in each group. Compared with the sham operation group, the LVEDP in the model group increased significantly, while the $\pm \mathrm{dp} / \mathrm{dt}_{\max }$ decreased

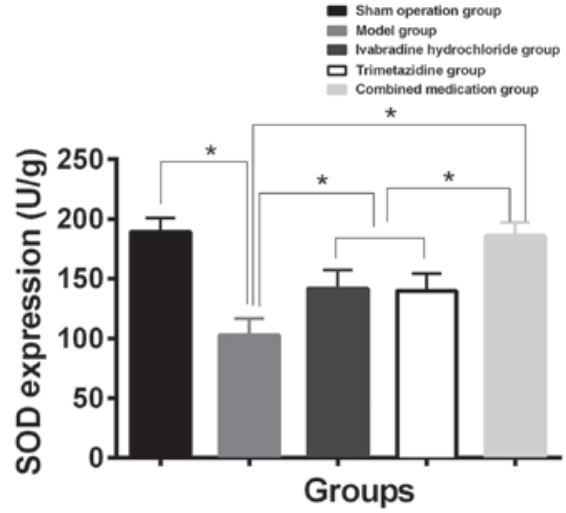

Figure 2. Expression of SOD in myocardial tissue of each group. Western blot analysis showed that compared with the sham operation group, SOD content decreased in myocardial tissue of the model group. Compared with the model group, the content increased in myocardial tissue of the Iva, trimetazidine and combined drug group $(\mathrm{P}<0.01)$. The changes in the combined drug group were the most notable $(\mathrm{P}<0.05)$, and the expression of SOD in the Iva group and trimetazidine group had no significant difference $(\mathrm{P}>0.05)$. ${ }^{*} \mathrm{P}<0.05$ SOD, superoxide dismutase.

significantly $(\mathrm{P}<0.05)$. Whereas, compared with the model group, the LVEDP in the Iva, trimetazidine and combined drug group decreased significantly, while the $\pm \mathrm{dp} / \mathrm{dt}_{\max }$ increased significantly $(\mathrm{P}<0.05)$. The changes in the combined drug group were the most notable $(\mathrm{P}<0.05)$, and the indexes in the Iva and trimetazidine group had no significant difference (P>0.05) (Table II).

Expression of CTGF and SOD in myocardial tissue of each group. Compared with the sham operation group, SOD content decreased and CTGF expression increased in myocardial tissue of the model group. While compared with the model group, SOD content increased and CTGF expression level decreased in myocardial tissue of the Iva, trimetazidine and combined drug group $(\mathrm{P}<0.01)$. The changes in the combined drug group were the most notable $(\mathrm{P}<0.05)$, and the expression levels of CTGF and SOD in the Iva and trimetazidine group had no significant difference $(\mathrm{P}>0.05)$ (Table III, Figs. 1 and 2).

Expression levels of TGF- $\beta 1$ and COL-I in myocardial tissue of each group. Compared with the sham operation group, the expression levels of TGF- $\beta 1$ mRNA and COL-I mRNA in myocardial tissue of model group increased, while compared with the model group, the expression levels decreased in myocardial tissues of the Iva, trimetazidine and combined drug group $(\mathrm{P}<0.05)$. Changes in the combined drug group 
Table III. Expression of CTGF and SOD in myocardial tissue of each group.

\begin{tabular}{|c|c|c|c|c|c|c|c|}
\hline Index & $\begin{array}{l}\text { Sham operation } \\
\text { group }(n=10)\end{array}$ & $\begin{array}{c}\text { Model } \\
\text { group }(n=10)\end{array}$ & $\begin{array}{l}\text { Iva group } \\
(\mathrm{n}=10)\end{array}$ & $\begin{array}{l}\text { Trimetazidine } \\
\text { group }(n=10)\end{array}$ & $\begin{array}{l}\text { Combined drug } \\
\text { group }(n=10)\end{array}$ & F value & $\mathrm{P}$-value \\
\hline CTGF & $0.162 \pm 0.023^{\mathrm{a}}$ & $0.488 \pm 0.022$ & $0.276 \pm 0.025^{\mathrm{a}, \mathrm{b}}$ & $0.281 \pm 0.031^{\mathrm{a}, \mathrm{b}}$ & $0.174 \pm 0.026^{\mathrm{a}}$ & 261.0 & $<0.001$ \\
\hline SOD (U/g) & $189.33 \pm 11.71^{\mathrm{a}}$ & $102.65 \pm 14.23$ & $141.82 \pm 15.31^{\mathrm{a}, \mathrm{b}}$ & $139.77 \pm 14.52^{\mathrm{a}, \mathrm{b}}$ & $185.69 \pm 11.39^{\mathrm{a}}$ & 71.30 & $<0.001$ \\
\hline
\end{tabular}

${ }^{a} \mathrm{P}<0.05$, compared with model group; ${ }^{\mathrm{b}} \mathrm{P}<0.05$, compared with drug group. CTGF, connective tissue growth factor; SOD, superoxide dismutase

Table IV. Expression of TGF- $\beta 1$ mRNA and COL-I mRNA in myocardial tissue of each group.

\begin{tabular}{|c|c|c|c|c|c|c|c|}
\hline Index & $\begin{array}{l}\text { Sham operation } \\
\text { group }(n=10)\end{array}$ & $\begin{array}{c}\text { Model } \\
\text { group }(n=10)\end{array}$ & $\begin{array}{l}\text { Iva group } \\
\quad(n=10)\end{array}$ & $\begin{array}{l}\text { Trimetazidine } \\
\text { group }(n=10)\end{array}$ & $\begin{array}{l}\text { Combined drug } \\
\text { group }(n=10)\end{array}$ & F value & P-value \\
\hline TGF- $\beta 1$ mRNA & $0.369 \pm 0.038^{\mathrm{a}}$ & $0.875 \pm 0.046$ & $0.631 \pm 0.039^{\mathrm{a}, \mathrm{b}}$ & $0.657 \pm 0.035^{\mathrm{a}, \mathrm{b}}$ & $0.439 \pm 0.042^{\mathrm{a}}$ & 328.4 & $<0.001$ \\
\hline COL-I mRNA & $0.635 \pm 0.051^{\mathrm{a}}$ & $1.211 \pm 0.049$ & $0.812 \pm 0.055^{\mathrm{a}, \mathrm{b}}$ & $0.826 \pm 0.048^{\mathrm{a}, \mathrm{b}}$ & $0.723 \pm 0.056^{\mathrm{a}}$ & 178.5 & $<0.001$ \\
\hline
\end{tabular}

${ }^{a} \mathrm{P}<0.05$, compared with model group; ${ }^{\text {}} \mathrm{P}<0.05$ compared with drug group. TGF- $\beta 1$, transforming growth factor- $\beta 1$; COL-I, collagen I.

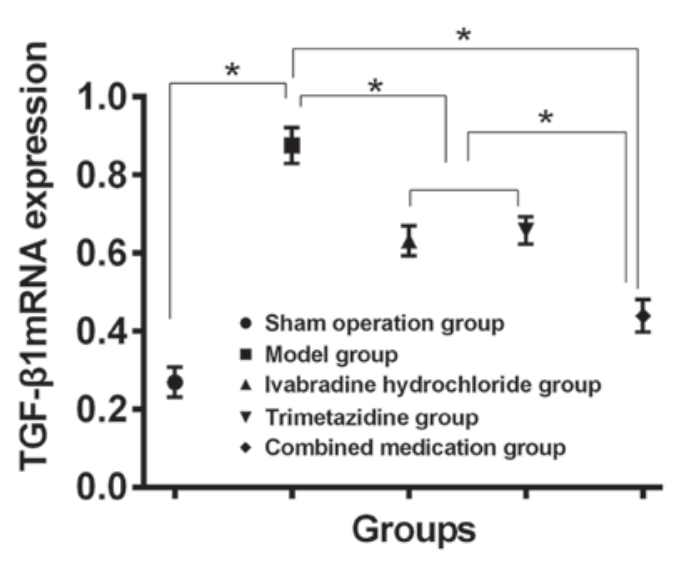

Figure 3. Expression of TGF- $\beta 1$ in myocardial tissue of each group. RT-qPCR showed that compared with the sham operation group, the expression of TGF- $\beta 1$ mRNA in myocardial tissue of model group increased. While compared with the model group, the expression decreased in myocardial tissues of the Iva, trimetazidine and combined drug group $(\mathrm{P}<0.05)$. The changes in the combined drug group were the most notable $(\mathrm{P}<0.05)$, and the expression of TGF- $\beta 1$ mRNA in the Iva and trimetazidine group had no significant difference $(\mathrm{P}>0.05)$. ${ }^{*} \mathrm{P}<0.05$. TGF- $\beta 1$, transforming growth factor $-\beta 1$.

were the most notable $(\mathrm{P}<0.05)$, and the expression of TGF- $\beta 1$ mRNA and COL-I mRNA in the Iva and trimetazidine group had no significant difference $(\mathrm{P}>0.05)$ (Table IV, and Figs. 3 and 4).

\section{Discussion}

The high incidence of hypertension, diabetes and coronary heart diseases caused by accelerated aging of the population and the improvement of living standards leads to a rising number of heart failure patients (12). In recent years, diuretics, $\beta$ receptor blockers are mostly used in clinical treatment of heart failure but achieving unsatisfactory efficacy and still high mortality rates $(13,14)$. A study pointed out that the decisive

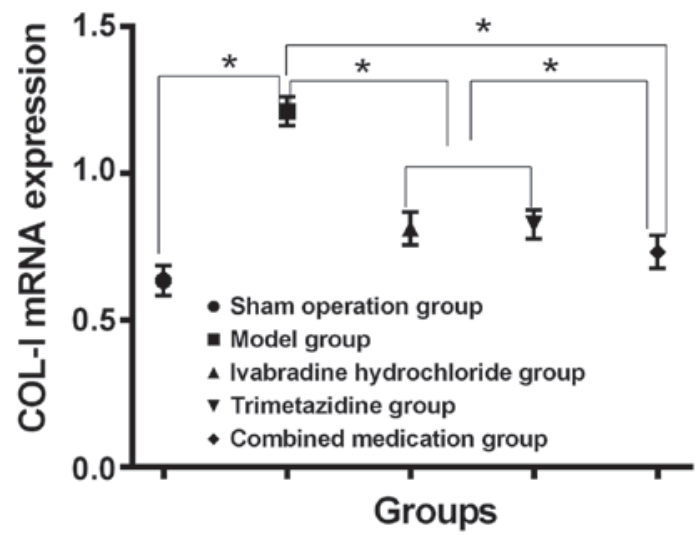

Figure 4. Expression of COL-I in myocardial tissue of each group. RT-qPCR showed that compared with the sham operation group, the expression of COL-I mRNA in myocardial tissue of model group increased. While compared with the model group, the expression decreased in myocardial tissues of the ivabradine hydrochloride, trimetazidine and combined drug group $(\mathrm{P}<0.05)$. The changes in the combined drug group were the most notable $(\mathrm{P}<0.05)$, and the expression of COL-I mRNA in the Iva and trimetazidine group had no significant difference $(\mathrm{P}>0.05)$. ${ }^{*} \mathrm{P}<0.05$. COL-I, collagen $\mathrm{I}$.

mechanism of CHF was ventricular remodeling, of which MF is the most significant (15). MF is reported to be an important pathological basis of heart failure, mainly referring to the remodeling of intermyocardial collagen network (ICN) (16). In this study, the CHF rat models were prepared by constricting the abdominal aorta, and the effects of Iva and trimetazidine alone and in combination on MF in CHF rats were explored.

LVEDP is often used to express cardiac volume load clinically. Some studies show that its increase leads to increased mitochondria and decreased adenosine triphosphate (ATP) in cardiac myocytes, promotes the synthesis of collagen fibers and eventually accelerates the process of MF in $\mathrm{CHF}$ rats $(16,17)$. Our experimental results showed that, compared with the sham operation group, the LVEDP in the model 
group increased significantly while the $\pm \mathrm{dp} / \mathrm{dt}_{\max }$ decreased significantly $(\mathrm{P}<0.05)$, which indicated that the model group rats developed MF. Compared with the model group, the LVEDP in the Iva group, trimetazidine group and combined drug group decreased significantly while the $\pm \mathrm{dp} / \mathrm{dt}_{\max }$ increased significantly $(\mathrm{P}<0.05)$. Moreover, the changes in the combined drug group were the most notable $(\mathrm{P}<0.05)$. The results suggested that both Iva and trimetazidine improved $\mathrm{MF}$ in rats, and the combined medication achieved a more obvious improvement, which was suspected to be related to the maximum rising and decreasing rate of left ventricular pressure in rats. A previous study (18) also reached the same conclusion as ours when discussing the effect of trimetazidine on MF in CHF rats, but there is no relevant study to explain it for the time being. SOD is an important antioxidant enzyme and a major substance for eliminating free radicals in vivo. CTGF is a factor that can induce fibroblast proliferation with obvious mitogen and chemotaxis. Both SOD and CTGF are important factors for evaluating MF $(19,20)$. Our results showed that, compared with the sham operation group, SOD content decreased and CTGF expression increased in myocardial tissue of the model group. Compared with the model group, SOD content increased and CTGF expression level decreased in myocardial tissue of the Iva group, trimetazidine group and combined drug group $(\mathrm{P}<0.05)$, but the changes in the combined drug group were the most notable $(\mathrm{P}<0.05)$. The results suggested that Iva and trimetazidine affected MF process through CTGF and SOD in myocardial tissue of CHF rats. A study (21) has shown that Iva could inhibit the oxidative stress reaction of myocardial cells in CHF rats, and another study (22) also showed that trimetazidine, as a new anti-myocardial ischemia drug, also had the function of oxygen free radical inhibition, oxidation resistance and apoptosis, which partially explained the changes in SOD expression in our conclusion. It was considered that (23) TGF- $\beta 1$, a multifunctional regulatory factor, could affect MF through Smads-dependent and Smads-independent pathways. There is also a study (24) showing that excessive synthesis and deposition of COL-I promoted MF in patients with hypertension and heart failure. Therefore, the expression levels of TGF- $\beta 1$ mRNA and COL-I mRNA in myocardial tissues were also detected in this study. The results showed that compared with the sham operation group, the expression levels of both TGF- $\beta 1$ mRNA and COL-I mRNA in myocardial tissues of the model group were increased. Compared with the model group, the expression levels decreased in myocardial tissues of the Iva group, trimetazidine group and combined drug group $(\mathrm{P}<0.05)$, and changes in the combined drug group were the most notable $(\mathrm{P}<0.05)$. The results suggested that both Iva and trimetazidine could inhibit the expression levels of TGF- $\beta 1$ and COL-I, and the inhibition effect was most pronounced when used in combination. The above results all suggest that Iva and trimetazidine can effectively inhibit MF in CHF rats, and the effect of combined administration is greater than that of the single drug. However, at present, there is no related research on the synergistic effect of the two drugs through different mechanisms.

Collectively, Iva combined with trimetazidine can inhibit MF in CHF rats by regulating LVEDP, SOD content and CTGF expression in myocardial tissue, and by inhibiting
TGF- $\beta 1 \mathrm{w}$ and COL-I expression, and the inhibition effect is most pronounced when used in combination. However, in our study, the specific mechanism of Iva and trimetazidine in regulating MF and the possible toxic and side effects of combined medication were not fully addressed, thus further studies are anticipated.

\section{Acknowledgements}

Not applicable.

\section{Funding}

This study was supported by Technology boosting and technology translation project of Jining City (No. 2017ZDGH031).

\section{Availability of data and materials}

The datasets used and/or analyzed during the present study are available from the corresponding author on reasonable request.

\section{Authors' contributions}

DMwrote the manuscript.TX,GCandXW performedqPCR and ELISA. ZL and XL were responsible for western blot analysis. JL and NY contributed to analysis of observation indexes. All the authors read and approved the final manuscript.

\section{Ethics approval and consent to participate}

The study was approved by the Ethics Committee of The Affiliated Hospital of Jining Medical University (Jining, China).

\section{Patient consent for publication}

Not applicable.

\section{Competing interests}

The authors declare that they have no competing interests.

\section{References}

1. Edelmann F, Knosalla C, Mörike K, Muth C, Prien P and Störk S: Chronic heart failure. Dtsch Arztebl Int 115: 124-130, 2018.

2. Füller M, von Bodman G, Kopf Dr, Brömsen J, Sodian R and Block M: Chronic heart failure with reduced ejection fraction: Standard treatment and new therapeutic options. MMW Fortschr Med 154: 63-70, 2012 (In German).

3. Lena A, Coats AJS and Anker MS: Metabolic disorders in heart failure and cancer. ESC Heart Fail 5: 1092-1098, 2018.

4. Gyöngyösi M, Winkler J, Ramos I, Do QT, Firat H, McDonald K, González A, Thum T, Díez J, Jaisser F, et al: Myocardial fibrosis: Biomedical research from bench to bedside. Eur J Heart Fail 19: 177-191, 2017.

5. Curtis LH, Whellan DJ, Hammill BG, Hernandez AF, Anstrom KJ, Shea AM and Schulman KA: Incidence and prevalence of heart failure in elderly persons, 1994-2003. Arch Intern Med 168: 418-424, 2008.

6. Hohendanner F, Messroghli D, Bode D, Blaschke F, Parwani A, Boldt LH and Heinzel FR: Atrial remodelling in heart failure: Recent developments and relevance for heart failure with preserved ejection fraction. ESC Heart Fail 5: 211-221, 2018.

7. Richards AM: ST2 and prognosis in chronic heart failure. J Am Coll Cardiol 72: 2321-2323, 2018. 
8. Hu DY, Huang DJ, Yuan ZY, Zhao RP, Yan XW and Wang MH; Chinese Investigators of SHIFT Study: Efficacy and safety analysis of ivabradine hydrochloride treatment of Chinese patients with chronic heart failure: Subgroup analysis of Chinese patients in the SHIFT study. Zhonghua Xin Xue Guan Bing Za Zhi 45: 190-197, 2017 (In Chinese).

9. Ke Y, Xu D, Li M, Wu Z and Huang Y: Effects of bisoprolol in combination with trimetazidine on the treatment of heart failure and concomitant chronic obstructive pulmonary disease. Pak J Med Sci 32: 1208-1212, 2016.

10. Fragasso G, Palloshi A, Puccetti P, Silipigni C, Rossodivita A, Pala M, Calori G, Alfieri O and Margonato A: A randomized clinical trial of trimetazidine, a partial free fatty acid oxidation inhibitor, in patients with heart failure. J Am Coll Cardiol 48: 992-998, 2006

11. Livak KJ and Schmittgen TD: Analysis of relative gene expression data using real-time quantitative PCR and the 2(-Delta Delta C(T)) method. Methods 25: 402-408, 2001.

12. Bernardi L, Spadacini G, Bellwon J, Hajric R, Roskamm H and Frey AW: Effect of breathing rate on oxygen saturation and exercise performance in chronic heart failure. Lancet 351: 1308-1311, 1998.

13. Suzuki T, Palus S and Springer J: Skeletal muscle wasting in chronic heart failure. ESC Heart Fail 5: 1099-1107, 2018.

14. Li CC, Chang SR and Shun SC: The self-care coping process in patients with chronic heart failure: A qualitative study. J Clin Nurs 28: 509-519, 2019.

15. López B, Querejeta R, González A, Sánchez E, Larman M and Díez J: Effects of loop diuretics on myocardial fibrosis and collagen type I turnover in chronic heart failure. J Am Coll Cardiol 43: 2028-2035, 2004.
16. Wang E-W, Jia X-S, Ruan C-W and Ge Z-R: miR-487b mitigates chronic heart failure through inhibition of the IL-33/ST2 signaling pathway. Oncotarget 8: 51688-51702, 2017.

17. Boivin-Jahns V and Jahns R: GPCR-autoantibodies in chronic heart failure. Front Biosci 23: 2065-2081, 2018

18. Brennan EJ: Chronic heart failure nursing: Integrated multidisciplinary care. Br J Nurs 27: 681-688, 2018.

19. Vergaro $\mathrm{G}$ and Iacoviello $\mathrm{M}$ : Is there a 'renal paradox' in chronic heart failure? Int J Cardiol 267: 139-140, 2018.

20. Canepa M, Ameri P, Lucci D, Nicolosi GL, Marchioli R, Porcu M, Tognoni G, Franzosi MG, Latini R, Maseri A, et al; GISSI-HF Investigators: Modes of death and prognostic outliers in chronic heart failure. Am Heart J 208: 100-109, 2018.

21. Freitas P, Ferreira AM and Aguiar C: Comparison of prognostic scores in chronic heart failure. JACC Heart Fail 6: 887-888, 2018

22. Simonavičius J, Knackstedt C and Brunner-La Rocca HP: Loop diuretics in chronic heart failure: How to manage congestion? Heart Fail Rev 24: 17-30, 2019.

23. Wolfson AM, Fong M, Grazette L, Rahman JE and Shavelle DM: Chronic heart failure management and remote haemodynamic monitoring. Heart 104: 1910-1919, 2018.

24. Fudim M, Ganesh A, Green C, Jones WS, Blazing MA,DeVore AD, Felker GM, Kiefer TL, Kong DF, Boortz-Marx RL, et al: Splanchnic nerve block for decompensated chronic heart failure: splanchnic-HF. Eur Heart J 39: 4255-4256, 2018.

This work is licensed under a Creative Commons

Attribution-NonCommercial-NoDerivatives 4.0 International (CC BY-NC-ND 4.0) License. 